\title{
PENGARUH RASIO KEUANGAN TERHADAP FINANCIAL DISTRESS PADA PERUSAHAAN SEKTOR INDUSTRI DASAR DAN KIMIA YANG TERDAFTAR DI BURSA EFEK INDONESIA
}

\author{
Andi Runis Makkulau \\ (Program Studi Manajemen, Sekolah Tinggi Ilmu Ekonomi Enam-Enam \\ Kendari) \\ Email: runispwt@gmail.com
}

\begin{abstract}
ABSTRAK
Penelitian ini bertujuan untuk mengetahui dan menganalisis pengaruh Current Ratio, Cash Ratio, Debt To Equity Ratio dan Sales Growth terhadap Financial Distress pada Perusahaan Sektor Industri Dasar dan Kimia yang Terdaftar di Bursa Efek Indonesia. Populasi dalam penelitian ini adalah perusahaan sektor industri dasar dan kimia yang terdaftar di Bursa Efek Indonesia. Berdasarkan metode purposive sampling, sampel yang diperoleh yaitu sebanyak 10 perusahaan. Penelitian ini menggunakan data kuantitatif dan bersumber dari jenis data sekunder yaitu data panel yang merupakan data gabungan dari data runtut waktu (time series data) dan data silang (cross section data). Hasil penelitian ini menunjukkan bahwa Current Ratio, Cash Ratio, Debt to Equity Ratio dan Sales Growth berpengaruh negatif tetapi tidak signifikan terhadap Financial Distress. Hal ini berarti bahwa Current Ratio, Cash Ratio, Debt to Equity Ratio dan Sales Growth tidak dapat menjelaskan Financial Distress.
\end{abstract}

Keywords: Current Ratio, Cash Ratio, Debt To Equity Ratio, Sales Growth, Financial Distress

\section{PENDAHULUAN}

Persaingan Industri Dasar dan Kimia di Indonesia semakin ketat, hal ini dapat di lihat dari jumlah perusahaan pada sektor tersebut yang terdaftar di Bursa Efek Indonesia (BEI) dari periode ke periodenya semakin bertambah. Berdasarkan data Bursa Efek Indonesia (BEI) sampai 31 Desember 2018, tercatat 71 perusahaan yang bergerak di Sektor Industri Dasar dan Kimia.

Financial distress terjadi sebelum perusahaan menghadapi kegagalan ataupun kebangkrutan. Kondisi financial distress merupakan kondisi keuangan dimana keuangan perusahaan dalam keadaan tidak sehat atau krisis. Financial distress yang cukup mengganggu kegiatan operasional perusahaan merupakan suatu kondisi yang harus segera diwaspadai dan 
diantisipasi. Menurut Rodoni dan Ali (2010: 176) apabila ditinjau dari kondisi keuangan ada tiga keadaan yang menyebabkan financial distress yaitu, faktor ketidakcukupan modal atau kekurangan modal, besarnya beban hutang dan bunga serta menderita kerugian. Ketiga aspek tersebut saling berkaitan. Oleh karena itu, harus dijaga keseimbangan agar perusahaan terhindar dari kondisi financial distress yang mengarah kepada kebangkrutan.

Banyak sekali literatur yang menggambarkan model prediksi kebangkrutan perusahaan, tetapi hanya sedikit penelitian yang berusaha untuk memprediksi financial distress suatu perusahaan. Hal ini dikarenakan sulit mendefinisikan secara objektif permulaan adanya financial distress. Analisis rasio keuangan dapat digunakan untuk memberi penilaian atas kinerja perusahaan, melalui rasio keuangan dapat digunakan sebagai dasar dalam memberikan penilaian atas pencapaian kinerja perusahaan. Analisis rasio keuangan akan memberikan informasi yang lengkap terkait dengan pencapaian kinerja keuangan perusahaan, baik ditinjau dari likuiditas, rentabilitas, solvabilitas, dan aktivitas yang dilakukan oleh perusahaan.

Rasio analisis tradisional hanya berfokus terhadap profitabilitas, solvency, dan likuiditas perusahaan yang mengalami kerugian tidak dapat membayar kewajiban atau likuid mungkin memerlukan restrukturisasi. Untuk mengetahui adanya gejala kebangkrutan diperlukan suatu model memprediksi financial distress untuk menghindari kerugian dalam investasi. Beberapa rasio yang peneliti gunakan untuk memprediksi kondisi financial distress yaitu rasio likuiditas, rasio leverage, rasio profitabilitas.

Financial leverage menunjukkan kemampuan perusahaan untuk memenuhi kewajiban baik itu jangka pendek maupun jangka panjang. Analisis terhadap rasio ini diperlukan untuk mengukur kemampuan perusahaan dalam membayar hutang (jangka pendek dan jangka panjang) apabila pada suatu saat perusahaan dilikuidasi atau dibubarkan (Sigit 2008). Dalam penelitian yang dilakukan oleh Almilia (2003) disebutkan bahwa rasio financial leverage yaitu variabel hutang lancar dibagi dengan total aktiva 
(CL/TA). Koefisien dalam Variabel CL/TA memiliki pengaruh negatif terhadap financial distress suatu perusahaan.

Variabel pertumbuhan penjualan mengacu pada penelitian yang dilakukan Almia (2006). Daulat (2008) bahwa current ratio, gross profit margin, dan rerun on investment berpengaruh terhadap financial distress. Sedangkan debt to equity ratio, total asset turnover tidak berpengaruh terhadap financial distress. Wahyu (2012) menujukkan bahwa return on equity, quick ratio, dan debt to equity ratio berpengaruh terhadap financial distress. Sedangkan current ratio dan sales growth tidak berpengaruh terhadap financial distress.

Ahmad (2012) menganalisis beberapa penyebab perusahaan mengalami financial distress, hasil penelitiannya menunjukkan bahwa current ratio, cash ratio, total liabilities to total asset, current liabilities to total asset, dan sales growth tidak berpengaruh negatif terhadap kondisi financial distress. Sebaliknya penelitian Diah (2010) profitabilitas berpengaruh signifikan terhadap financial distress perusahaan artinya semakin besar profitabilitas semakin mengurangi kondisi financial distress perusahaan.

Ada dua motif dilakukannya penelitian tentang prediksi financial distress perusahaan, yang pertama adalah untuk menguji hubungan dan pengaruh antar variabel faktor keuangan dan pengukuran kegagalan atau kebangkrutan, sedangkan yang kedua adalah untuk mengembangkan model dalam peramalan atau prediksi kebangkrutan (Brahmana, 2007) penelitian ini dilakukan dengan motif pertama yaitu menguji pengaruh rasio keuangan terhadap financial distress perusahaan.

\section{TINJAUAN PUSATAKA}

\section{Rasio Keuangan}

Menurut Widjaja (2010:12), rasio dapat didefinisikan sebagai berikut: "Rasio adalah satu angka yang dinyatakan dalam hubungannya dengan yang lain. Banyak rasio yang dihitung dari satu kumpulan laporan keuangan, tetapi biasanya hanya sedikit yang bermanfaat dalam situasi tertentu." Kieso dan Kimmel dalam Adhariani dan Diyanti (2008:395), menyatakan bahwa: "Rasio menyatakan hubungan matematik antara satu kuantitas dengan lainnya. 
Hubungan tersebut dinyatakan dalam bentuk persentase, tingkat, atau proporsi sederhana. Dan Analisis rasio menyatakan hubungan diantara pospos tertentu dari data laporan keuangan".

\section{Financial Distress}

Financial distress atau kesulitan keuangan dapat diartikan sebagai ketidakmampuan perusahaan untuk membayar kewajiban keuangannya pada saat jatuh tempo yang menyebabkan kebangkrutan perusahaan (Darsono dan Ashari, 2005 dalam Kartikawati, 2008). Financial Distress juga didefinisikan sebagai tahap penurunan kondisi keuangan yang terjadi sebelum kebangkrutan atau likuidasi (Platt dan Platt, 2002 dalam Iramani, 2007).

Kesulitan keuangan bisa digambarkan di antara dua titik ekstrim yaitu kesulitan likuiditas jangka pendek (yang paling ringan) sampai insolvency (yang paling parah). Kesulitan keuangan jangka pendek biasanya bersifat sementara. Salah satu aspek pentingnya analisis terhadap laporan keuangan dari sebuah perusahaan adalah kegunaannya untuk meramal kontinuitas atau kelangsungan hidup perusahaan. Prediksi kelangsungan hidup perusahaan sangat penting bagi manajemen dan pemilik perusahaan untuk mengetahui kondisi keuangan perusahaan dan mengantisipasi kondisi yang menyebabkan kemungkinan adanya potensi kebangkrutan.

\section{Faktor-faktor Penyebab Kebangkrutan}

Menurut Munawir (2004:289) secara garis besar penyebab kebangkrutan biasa dibagi menjadi dua yaitu faktor internal perusahaan maupun eksternal baik yang bersifat khusus yang berkaitan langsung dengan perusahaan maupun yang bersifat umum. Jauch dan Glueck dalam Adnan (2000: 139) faktor-faktor yang menyebabkan terjadinya kebangkrutan pada perusahaan adalah:

a. Faktor umum

1) Sektor ekonomi

Faktor-faktor penyebab kebangkrutan dari sektor ekonomi adalah gejala inflasi dan deflasi dalam harga barang dan jasa, kebijakan keuangan, suku bunga dan devaluasi atau revaluasi uang dalam 
hubungannya dengan uang asing serta neraca pembayaran, surplus atau defisit dalam hubungannya dengan perdagangan luar negeri.

2) Sektor sosial

Faktor sosial sangat berpengaruh terhadap kebangkrutan cenderung pada perubahan gaya hidup masyarakat yang mempengaruhi permintaan terhadap produk dan jasa ataupun cara perusahaan berhubungan dengan karyawan.

3) Teknologi

Penggunaan teknologi informasi juga menyebabkan biaya yang ditanggung perusahaan membengkak terutama untuk pemeliharaan dan implementasi. Pembengkakan terjadi, jika penggunaan teknologi informasi tersebut kurang terencana oleh pihak manajemen, sistemnya tidak terpadu dan para manajer pengguna kurang profesional.

4) Sektor pemerintah

Pengaruh dari sektor pemerintah berasal dari kebijakan pemerintah terhadap pencabutan subsidi pada perusahaan dan industri, pengenaan tarif ekspor dan impor barang berubah, kebijakan undang-undang baru bagi perbankan atau tenaga kerja dan lainlain.

b. Faktor eksternal perusahaan

1) Faktor pelanggan / konsumen

Perusahaan harus bisa mengidentifikasi sifat konsumen, karena berguna untuk menghindari kehilangan konsumen, juga untuk menciptakan peluang untuk menemukan konsumen baru dan menghindari menurunnya hasil penjualan dan mencegah konsumen berpaling ke pesaing.

2) Faktor kreditur

Kekuatannya terletak pada pemberian pinjaman dan mendapatkan jangka waktu pengembalian hutang yang tergantung kepercayaan kreditur terhadap kelikuiditasan suatu perusahaan. 
3) Faktor pesaing

Faktor ini merupakan hal yang harus diperhatikan karena menyangkut perbedaan pemberian pelayanan kepada konsumen, perusahaan juga jangan melupakan pesaingnya karena jika produk pesaingnya lebih diterima oleh masyarakat perusahaan tersebut akan kehilangan konsumen dan mengurangi pendapatan yang diterima.

c. Faktor internal perusahaan

Faktor-faktor yang menyebabkan kebangkrutan secara internal menurut Harnanto (1992:488-495)sebagai berikut:

1) Terlalu besarnya kredit yang diberikan kepada nasabah sehingga akan menyebabkan adanya penunggakan dalam pembayaran sampai akhirnya tidak dapat membayar.

2) Manajemen tidak efisien yang disebabkan karena kurang adanya kemampuan, pengalaman, keterampilan, sikap inisiatif dari manajemen.

3) Penyalahgunaan wewenang dan kecurangan dimana sering dilakukan oleh karyawan, bahkan manajer puncak sekalipun sangat merugikan apalagi yang berhubungan dengan keuangan perusahaan.

\section{Manfaat Informasi Prediksi Financial Distress dan Kepailitan}

Widiyaningsih (2008) menyatakan kegunaan informasi jika suatu perusahaan mengalami Financial Distress adalah:

a. Dapat mempercepat tindakan manajemen untuk mencegah masalah sebelum terjadinya kebangkrutan.

b. Pihak manajemen dapat mengambil tindakan merger atau takeover agar perusahaan lebih mampu untuk membayar hutang dan mengelola perusahaan dengan baik.

c. Memperbaiki tanda peringatan awal adanya kebangkrutan pada masa yang akan datang. 


\section{METODE PENELITIAN}

\section{Jenis dan Sumber Data}

Penelitian ini menggunakan data kuantitatif dan bersumber dari jenis data sekunder yaitu data panel yang merupakan data gabungan dari data runtut waktu (time series data) dan data silang (cross section data). Datadata yang digunakan menggunakan data dari laporan tahunan perusahaan khususnya keuangan perusahaan sektor industri dasar dan kimia yang terdaftar di Bursa Efek Indonesia yang dipublikasikan pada tahun 2014-2018. Data yang digunakan diperoleh melalui situs http:// www.idx.co.id.

\section{Metode Analisis Data}

a. Analisis Regresi

Metode analisis yang digunakan adalah model regresi linier berganda. Menurut Sugiyono (2014:277) bahwa: "Analisis regresi linier berganda bermaksud meramalkan bagaimana keadaan (naik turunnya) variable dependen (kriterium), bila dua atau lebih variable independen sebagai factor predictor dimanipulasi (dinaik turunkan nilainya). Jadi analisis regresi berganda akan dilakukan bila jumlah variable independennya minimal 2".

Menurut Sugiyono (2014:277) persamaan regresi linier berganda yang ditetapkan adalah sebagai berikut:

$$
\mathrm{Y}=\alpha+\beta 1 \mathrm{X} 1+\beta 2 \mathrm{X} 2+\beta 3 \mathrm{X} 3+\beta 4 \mathrm{X} 4+\mathrm{e}
$$

Keterangan:

Y : Financial Distress

a : Konstanta

$\beta 1$ : Koefisien regresi

X1 : Current Ratio; X2 : Cash Ratio; X3 : Debt To Equity Ratio; X4 : Sales Growth

e : Error

Dalam statistik di atas suatu hipotesis dapat diterima jika tingkat signifikansi $5 \%$, dan jika tingkat signifikansi dari hasil analisis kurang dari 0,05 maka hipotesis diterima. 


\section{Definisi Operasional Variabel}

\section{a. Variabel Dependen}

Dalam penelitian ini variabel dependennya adalah Financial Distress. Dalam menentukan perusahaan yang mengalami kondisi financial distress dengan melihat kondisi perusahaan tidak sehat yang ditandai dengan terjadinya laba bersih negatif 2 tahun berturut-turut, sebagaimana dikatakan oleh Whitaker (1999) yang mendefinisikan financial distress sebagai suatu perusahaan mengalami laba bersih (net income) negatif selama beberapa tahun.

Berdasarkan hal tersebut, peneliti menentukan data financial distress dengan nilai 1 jika perusahaan memiliki laba bersih negatif selama dua tahun berturut-turut, dan 0 jika memiliki laba bersih positif selama dua tahun berturut-turut.

b. Variabel Independen

\section{Current Ratio}

$$
\text { Current Ratio }=\frac{\text { Asset lancar }}{\text { Utang lancar }}
$$

Cash Ratio

$$
\text { Cash Ratio }=\frac{\text { Cash }+ \text { Equivalen }}{\text { Curent Liabilities }}
$$

Total Debt To Equity Ratio

$$
\text { Debt to Equity Ratio }=\frac{\text { Jumlah hutang }}{\text { Modal sendiri/Ekuitas }}
$$

\section{Sales Growth}

$$
\text { Sales Growth }=\frac{\text { Sales periode sekarang }- \text { Sales periode sebelumnya }}{\text { Sales periode sebelumnya }}
$$

\section{HASIL PENELITIAN DAN PEMBAHASAN}

\section{Analisis Regresi}

Berdasarkan pemilihan model estimasi di atas bahwa Random Effect Model adalah model yang paling cocok digunakan pada penelitian ini. Berikut ini hasil output pengolahan data untuk regresi data panel pada perusahaan 
Sektor Industri Dasar dan Kimia yang terdaftar di Bursa Efek Indonesia tahun 2014-2018:

Tabel 1. Hasil Regresi Data Panel

\begin{tabular}{|c|c|c|c|c|}
\hline \multicolumn{5}{|c|}{$\begin{array}{l}\text { Dependent Variable: Y } \\
\text { Method: Panel EGLS (Cross-section random effects) } \\
\text { Date: 09/16/19 Time: 18:35 } \\
\text { Sample: } 20142018 \\
\text { Periods included: } 5 \\
\text { Cross-sections included: } 10 \\
\text { Total panel (balanced) observations: } 50 \\
\text { Swamy and Arora estimator of component variances } \\
\end{array}$} \\
\hline Variable & Coefficient & Std. Error & t-Statistic & Prob. \\
\hline $\mathrm{C}$ & 0.924302 & 0.208027 & 4.443175 & 0.0001 \\
\hline $\mathrm{X} 1$ & -0.175760 & 0.151499 & -1.160141 & 0.2521 \\
\hline $\mathrm{X} 2$ & 0.022613 & 0.081873 & 0.276189 & 0.7837 \\
\hline $\mathrm{X} 3$ & -0.000994 & 0.009448 & -0.105231 & 0.9167 \\
\hline $\mathrm{X} 4$ & -1.802205 & 0.000341 & -0.052849 & 0.9581 \\
\hline
\end{tabular}

\begin{tabular}{lr|r|r|}
\hline \hline & & & \\
& Effects Specification & \multicolumn{1}{c}{ S.D. } & \multicolumn{1}{c}{ Rho } \\
\hline \hline Cross-section random & 0.328593 & 0.4760 \\
\hline Idiosyncratic random & 0.344795 & 0.5240 \\
\hline \hline
\end{tabular}

Weighted Statistics

\begin{tabular}{l|r|r|r|}
\hline \hline R-squared & 0.035192 & Mean dependent var & 0.322860 \\
\hline Adjusted R-squared & 0.050569 & S.D. dependent var & 0.327383 \\
\hline S.E. of regression & 0.335559 & Sum squared resid & 5.066991 \\
\hline \multicolumn{3}{|l|}{} \\
\hline F-statistic & 0.410352 & Durbin-Watson stat & 1.868971 \\
\hline Prob(F-statistic) & 0.800229 & & \\
\hline
\end{tabular}

Unweighted Statistics

\begin{tabular}{|l|c|c|r|}
\hline \hline R-squared & 0.070293 & Mean dependent var & 0.760000 \\
\hline Sum squared resid & 8.478931 & Durbin-Watson stat & 1.116893 \\
\hline
\end{tabular}

Sumber: Data Diolah dengan Eviews 10

Berdasarkan tabel di atas, maka diperoleh persamaan regresi data panel sebagai berikut:

Financial Distress $=0,924302-0,175760+0,022613-0,000994-1,802205$

Persamaan regresi tersebut dapat disimpulkan bahwa nilai koefisien konstanta (C) sebesar 0,924302 artinya jika variabel X1 (Current Ratio), X2 
(Cash Ratio), X3 (Debt To Equity Ratio), X4 (Sales Growth) adalah nol, maka besarnya financial distress sebesar 0,924302.

Nilai koefisien regresi variabel X1 (Current Ratio) bernilai negatif yaitu sebesar -0,175760 artinya setiap peningkatan 1\% Current Ratio diprediksi akan menurunkan financial distress sebesar $-0,175760$ dengan asumsi nilai variabel lainnya tetap.

Nilai koefisien regresi variabel X2 (Cash Ratio) bernilai positif yaitu sebesar 0,022613 artinya setiap peningkatan 1\% Cash Ratio diprediksi akan meningkatkan financial distress sebesar 0,022613 dengan asumsi variabel lainnya tetap.

Nilai koefisien regresi variabel X3 (Debt To Equity Ratio) bernilai negatif yaitu sebesar -0,000994 artinya setiap peningkatan 1\% Debt To Equity Ratio diprediksi akan menurunkan financial distress sebesar -0,000994 dengan asumsi variabel lainnya tetap.

Nilai koefisien regresi variabel X4 (Sales Growth) bernilai negatif yaitu sebesar -1,802205 artinya setiap peningkatan 1\% Sales Growth diprediksi akan menurunkan financial distress sebesar -1,802205 dengan asumsi variabel lainnya tetap.

\section{Hasil Uji Hipotesis}

\section{a. Uji Parsial (Uji t)}

Uji parsial atau uji t digunakan untuk mengetahui pengaruh masingmasing variabel independen dalam menerangkan variasi variabel dependen. Dengan tingkat signifikansi pada penelitian ini adalah 5\% (0.05). Berikut ini hasil pengujian hipotesis secara parsial:

Tabel 2. Hasil Pengujian Hipotesis Secara Parsial

\begin{tabular}{|c|c|c|c|c|c|}
\hline Variable & Coefficient & Std. Error & t-Statistic & Prob. & Ket \\
\hline C & & & & & \\
\hline X1 (Current Ratio) & 0.924302 & 0.208027 & 4.443175 & 0.0001 & - \\
\hline X2 (Cash Ratio) & -0.175760 & 0.151499 & -1.160141 & 0.2521 & TS \\
\hline X3 (DER) & 0.022613 & 0.081873 & 0.276189 & 0.7837 & TS \\
\hline X4 (Sales Growth) & -0.000994 & 0.009448 & -0.105231 & 0.9167 & TS \\
\hline
\end{tabular}

Sumber: Data Diolah dengan Eviews 10 
Hipotesis penelitian bersifat dua arah maka t-tabel pengujian satu variabel dependen dan 4 variabel independen dengan tingkat signifikansi 5\% yaitu $(\mathrm{df})=(\mathrm{n}-(\mathrm{k}-1)=50-(5-1)=46$ maka diperoleh t-tabel $=2,01290$. Jika $\mathrm{t}-$ hitung bernilai negatif maka dibandingkan dengan t-tabel yang bernilai negatif begitupun sebaliknya jika t-hitung bernilai positif maka dibandingkan dengan t-tabel bernilai positif.

Berdasarkan tabel di atas variabel Current Ratio (X1) terhadap financial distress menunjukkan hasil t-hitung sebesar -1,160141. Karena thitung < t-tabel $(-1.160141<-2,01290)$, Ha ditolak dan tingkat signifikansi ( $p$ value $=0,2521$ artinya lebih dari 0,05 demikian dapat disimpulkan bahwa Current Ratio tidak berpengaruh terhadap financial distress.

Variabel Cash Ratio (X2) terhadap financial distress menunjukkan hasil t-hitung sebesar 0.276189. Karena t-hitung < t-tabel $(0.276189<$ 2,01290), Ha ditolak dan tingkat signifikansi ( $p$-value) $=0.7837$ artinya lebih dari 0,05 demikian dapat disimpulkan bahwa Cash Ratio tidak berpengaruh terhadap financial distress.

Variabel Debt To Equity Ratio (X3) terhadap financial distress menunjukkan hasil t-hitung sebesar -0.105231 . Karena t-hitung < t-tabel ($0.105231<-2,01290)$, Ha ditolak dan tingkat signifikansi ( $p$-value) $=0.9167$ artinya lebih dari 0,05 demikian dapat disimpulkan bahwa Debt To Equity Ratio tidak berpengaruh terhadap financial distress.

Variabel Sales Growth (X4) terhadap financial distress menunjukkan hasil t-hitung sebesar -0.052849 . Karena t-hitung < t-tabel $(-0.052849<-$ $2,01290)$, Ha ditolak dan tingkat signifikansi ( $p$-value) $=0.9581$ artinya lebih dari 0,05 demikian dapat disimpulkan bahwa Sales Growth tidak berpengaruh terhadap financial distress.

b. Koefisien Determinasi (R2)

Besarnya hubungan current ratio, cash ratio, debt to equity ratio dan sales growth terhadap financial distress pada perusahaan sektor industri dasar dan kimia yang terdaftar di BEl pada tahun 2014-2018 dapat ditunjukkan oleh koefisien determinasi. Berdasarkan tabel 4.6 di atas koefisien determinasi dapat dilihat pada Adjusted $R$-Square yaitu sebesar 
0,050569 atau 5,0569\% artinya bahwa variabel current ratio, cash ratio, debt to equity ratio dan sales growth memiliki kemampuan dalam rangka menerangkan pada variabel financial distress sebesar 5,0569\%. Sedangkan sisanya sebesar $94,9431 \%$ dijelaskan oleh faktor lain yang tidak tidak diteliti dalam penelitian ini. Dengan memperhatikan besarmya Adjusted R-Square sebesar 5,0569\% yang artinya tingkat hubungan variabel current ratio, cash ratio, debt to equity ratio dan sales growth terhadap financial distress sangat lemah.

\section{Pembahasan}

\section{a. Pengaruh Current Ratio terhadap Financial Distress}

Berdasarkan hasil uji regresi menunjukkan bahwa tidak terdapat pengaruh dan signifikan antara variabel Current Ratio terhadap Financial Distress. Sehingga hal ini, Current Ratio tidak memiliki pengaruh signifikan terhadap Financial Distress. Hal tersebut dikarenakan bahwa pada perusahaan yang menjadi sampel dalam penelitian ini memiliki kemampuan mendanai operasional perusahaan dalam memenuhi kewajiban (utang) jangka pendek dengan hutang lancar yang dimilikinya. Oleh karena itu perusahaan mengelola hutang lancar dengan aktiva yang dimiliknya dengan baik sehingga tidak terjadi financial distress.

Hal ini berbeda dengan yang dijelaskan oleh Munthe (2008) semakin tinggi rasio likuiditas maka semakin baik kondisi keuangan perusahaan karena menunjukkan bahwa perusahaan dalam keadaan yang likuid. Semakin tinggi rasio likuiditas, maka semakin kecil kemungkinan perusahaan akan mengalami Financial Distress, akan tetapi rasio likuiditas yang terlalu tinggi menunjukkan bahwa modal kerja perusahaan tidak produktif mengakibatkan munculnya biaya-biaya yang akan mengurangi laba perusahaan dan akan berpengaruh positif terhadap Financial Distress. Hasil penelitian ini sesuai dengan hasil penelitian Wahyu (2012) Current Ratio tidak berpengaruh terhadap financial distress.

\section{b. Pengaruh Cash Ratio Terhadap Financial Distress}

Hasil uji regresi menunjukkan bahwa tidak terdapat pengaruh antara variabel Cash Ratio terhadap Financial Distress. Sehingga hal ini, Cash Ratio 
tidak memiliki pengaruh terhadap Financial Distress. Hal tersebut dikarenakan besar kecilnya nilai Cash Ratio tidak mampu mendefinisikan bahwa suatu perusahaan akan mengalami Financial Distress, kondisi cash ratio yang tinggi akan semakin baik bagi perusahaan karena kemampuan perusahaan dalam membayar hutang-hutang jangka pendeknya akan semakin baik sehingga perusahaan dapat terhindar dari financial distress. Namun, semakin besarnya cash ratio maka mengindikasikan bahwa ada banyak dana yang menganggur atau belum digunakan secara optimal. Sehingga kemampuan perusahaan dalam menghasilkan laba berkurang. Berkurangnya laba perusahaan tentunya akan membuat investor menarik dananya karena pembagian dividen akan semakin kecil. Tentunya perusahaan akan kekurangan modal dan memicu terjadinya financial distress.

Hal ini berbeda dengan yang dijelaskan oleh Sawir (2009) bahwa cash ratio merupakan rasio yang menunjukan posisi kas yang dapat menutupi hutang lancar dengan kata lain Cash Ratio merupakan rasio yang menggambarkan kemampuan kas yang dimiliki dalam manajemen kewajiban lancar tahun yang bersangkutan. Penelitian ini sesuai dengan hasil penelitian Widarjo (2009) bahwa likuiditas yang dihitung dengan Cash Ratio menunjukan Cash Ratio tidak berpengaruh terhadap kondisi Financial Distress.

c. Pengaruh Debt to Equity Ratio terhadap Financial Distress

Dalam uji regresi menunjukkan bahwa tidak terdapat pengaruh antara variabel DER terhadap Financial Distress. Sehingga hal ini, DER tidak memiliki pengaruh terhadap Financial Distress. Hal tersebut dikarenakan perusahaan dengan DER yang tinggi belum tentu dikategorikan sebagai perusahaan yang mengalami financial distress, demikian pula dengan perusahaan dengan nilai DER yang lebih rendah belum tentu dikategorikan sebagai perusahaan non financial distress. Sehingga hutang yang diproksikan dengan DER tidak mampu memprediksi financial distress suatu perusahaan, karena perusahaan dalam memperoleh sumber dana akan memilih yang risikonya kecil dan akan meningkatkan pengelolaan 
perusahaan sehingga akan memperoleh keuntungan yang tinggi. Kasmir (2016:158) juga menjelaskan bahwa bagi pihak kreditur nilai DER yang tinggi akan semakin tidak menguntungkan karena akan semakin besar risiko yang ditanggung atas kegagalan yang mungkin terjadi di masa yang akan datang. Namun bagi perusahaan nilai DER yang tinggi akan semakin baik, karena jika nilai DER rendah maka akan semakin tinggi dana yang harus disediakan oleh pemilik perusahaan

Hal ini berbeda dengan pendapat Sigit (2008) Debt to Equity Ratio menunjukkan kemampuan perusahaan untuk memenuhi kewajiban baik untuk jangka pendek maupun jangka panjang. Analisis terhadap rasio ini diperlukan untuk mengukur kemampuan perusahaan dalam membayar hutang (jangka pendek dan jangka panjang) apabila pada suatu saat perusahaan dilikuidasi atau dibubarkan. Penelitian ini sesuai dengan hasil penelitian Wahyu (2008) dan Daulat (2008) yang menujukan bahwa Debt To Equity Ratio tidak berpengaruh terhadap Financial Distress.

\section{d. Pengaruh Sales Growth terhadap Financial Distress}

Hasil uji regresi menunjukkan bahwa tidak terdapat pengaruh antara variabel Sales Growth terhadap Financial Distress. Sehingga hal ini, Sales Growth tidak memiliki pengaruh terhadap Financial Distress. Hal tersebut dapat disebabkan karena sampel perusahaan memiliki penjualan yang relatif stabil dan lebih aman memperoleh pinjaman sehingga dapat menanggung beban jika penjualan tidak stabil. Perusahaan yang memiliki nilai sales growth yang tinggi dapat mempertahankan kelangsungan hidup perusahaan dikarenakan laba perusahaan tersebut semakin meningkat. Nilai sales growth yang rendah akan berpengaruh terhadap penurunan laba, tetapi penurunan laba perusahaan yang terjadi tidak akan menyebabkan perusahaan mengalami kondisi financial distress.

Hal ini berbeda dengan pendapat Houston (2006:39) berpendapat bahwa perusahaan dengan penjualan yang relatif stabil dapat lebih aman memperoleh lebih banyak pinjaman dan menanggung beban tetap lebih tinggi dibandingkan dengan perusahaan yang penjualannya tidak stabil. Penelitian ini sesuai dengan hasil penelitian Widarjo (2009) bahwa Sales 
Growth tidak berpengaruh terhadap kondisi Financial Distress dan juga penelitian dari Wahyu (2012) bahwa Sales Growth tidak berpengaruh terhadap Financial Distress.

\section{KESIMPULAN}

\section{Kesimpulan}

Penelitian ini dilakukan untuk menguji apakah Current Ratio, Cash Ratio sebagai rasio likuiditas, Debt to Equity Ratio sebagai rasio leverage dan Sales Growth berpengaruh terhadap Financial Distress. Berdasarkan hasil pengujian secara parsial seluruh variable yaitu Current Ratio, Cash Ratio, Debt to Equity Ratio, dan Sales Growth tidak ada satupun yang berpengaaruh terhadap Financial Distress. Hal ini menunjukkan bahwa variable-variabel tersebut bukanlah faktor yang mempengaruhi sangat besar terhadap kondisi Financial Distress atau kesulitan keuangan yang dialami oleh Perusahaan-perusahaan Sektor Industri Dasar dan Kimia yang terdaftar di Bursa Efek Indonesia. Sehinnga perubahan besar atau kecilnya nilai Current Ratio, Cash Ratio, Debt to Equity Ratio, dan Sales Growth perusahaan bukanlah menjadi indikasi terkuat perusahaan mengalami Financial Distress, hal ini dapat disebabkan oleh faktor-faktor lain yang tidak di teliti dalam penelitian ini.

\section{Saran}

Berdasarkan hasil penelitian yang telah dilakukan pada perusahaan Sektor Industri Dasar dan Kimia yang Terdaftar di Bursa Efek Indonesia maka peneliti ingin memberikan saran-saran sebagai berikut:

\section{a. Bagi Perusahaan}

Hasil dari analisis prediksi kebangkrutan tidak sepenuhnya tepat dalam memprediksi kebangkrutan, namun hasil analisis tetap penting dilakukan untuk memberikan peringatan-peringatan dini tentang adanya prediksi kesulitan keuangan pada suatu perusahaan, sehingga perusahaan dapat melakukan langkah-langkah perbaikan untuk memperbaiki kinerjanya.

b. Bagi Investor 
Diharapkan dapat menjadi pertimbangan dalam melakukan investasi dan investor harus benar-benar selektif.

c. Bagi Peneliti Selanjutnya

Untuk mendapatkan hasil yang lebih baik pada penelitian selanjutnya, sebaiknya menambahkan variable atau menggunakan jenis-jenis rasio keuangan yang lain yang belum tercantum pada penelitian ini serta memiliki berpengaruh pada Financial Distress dan objek penelitian nya menggunakan perusahaan selain perusahaan yang peneliti gunakan.

\section{DAFTAR PUSTAKA}

Adisasmita, Rahardjo. 2005. Dasar-Dasar Ekonomi Wilayah. Yogyakarta: Graha IImu.

Adnan, M.A. dan Kurniasih, E. 2000. Analisis Tingkat Kesehatan Perusahaan untuk Memprediksi Potensi Kebangkrutan pada Pendekatan Altman (Kasus pada Sepuluh Perusahaan di Indonesia). Jurnal Akuntansi dan Auditing Indonesia. 4(2).

Ahmad. 2012. Prediction of Financial Distress Companies in the Consumer Products Sector in Malaysia. Jurnal UTM 2013, h. 1-12

Ali, Herni dan Ahmad Rodoni. 2010. Manajemen Keuangan. Jakarta: Mitra Wacana Media.

Almilia, Kristijadi, 2003. Analisis Rasio Keuangan untuk memprediksi Kondisi Financial Distress Perusahaan manufaktur yang terdaftar di BEJ. Jurnal Akuntansi dan Auditing Indonesia, Vol. 7 No. 2.

Arifin, Johar. 2003. Analisis Laporan Keuangan Berbasis Komputer. Jakarta: PT. Alex Media Komputindo Gramedia.

Atmini, S dan A. Wuryan. 2005. Manfaat Laba dan Arus Kas untuk memprediksi Kondisi Financial Distress Pada Perusahaan Textile Mill Products Dan Apparel And Other Textile Products yang terdaftar di Bursa Efek Jakarta. Makalah yang disampaikan pada Simposium Nasional Akuntansi VIII. Solo, 15-16 September.

Bastian, Idra dan Suhardjono. 2006. Akuntansi Perbankan Buku Dua Edisi Pertama. Jakarta: Salemba Empat.

Brahmana, R. 2007. Identifying Financial Distress Condition in Indonesia Manufacture Industry."Journal of accounting", h. 5-51. 
Darsono, Ashari. 2005. Pedoman Praktis Memahami Laporan Keuangan. Yogyakarta: CV Andi Offset.

Diah. Arini. 2010. Analisis Rasio Keuangan Untuk Memprediksi Kondisi Financial distress Perusahaan Manufaktur Yang Terdaftar Di Bursa Efek Jakarta. Skripsi thesis, Universitas Muhammadiyah Surakarta.

Dwi Mar'atus Sholihah. 2011. analisis potensi kebangkrutan perusahaan sektor textile dan garment di bursa efek Indonesia periode 2007-2009. Jurnal Emba Vol 2:121.

Endang A. 2012. Pengaruh Kinerja Keuangan dan Sensitivitas Perusahaan terhadap Faktor-Faktor Ekonomi Makro dalam Memprediksi Kondisi Financial distresspada Perusahaan Manufaktur yang Terdaftar Di Bursa Efek Indonesia. Prosiding

Ghozali, H. Imam. 2013. Aplikasi Analisis Multivariate dengan Program IBM SPSS 19. Edisi 5. Semarang: Badan Penerbit Universitas Diponegoro.

Hanafi, Mamduh dan Abdul Halim. 2003. Analisis Laporan Keuangan Edisi Revisi. Yogyakarta: UPP AMP YKPN.

Hanafi, Mamduh M. 2005. Manajemen Keuangan. Yogyakarta: BPFE.

Harnanto. 1992. Akuntansi Biaya : Perhitungan Harga Pokok Produk, Edisi Pertama. Yogyakarta: BPFE.

Hery. 2012. Analisis Laporan Keuangan. Jakarta: Bumi Aksara.

https://www.idx.co.id

Ikatan Akuntan Indonesia. 2007. Standar Akuntansi Keuangan. Salemba Empat: Jakarta.

Jogiyanto, H. 2013. Metodologi Penelitian Bisnis Salah Kaprah dan Pengalaman-Pengalaman, Edisi Keenam. Yogyakarta: BPFE.

Kieso, Donald E., dkk. 2008. Pengantar Akuntansi Edisi 7 (Alih Bahasa Desi Adhariani dan Vera Diyanti). Jakarta: Salemba Empat.

Munawir. 2004. Analisis Laporan Keuangan Edisi Ke-4. Yogyakarta: Liberty.

Munthe, Bermawi. 2009. Desain Pembelajaran. Yogyakarta: Pustaka Insani Madani.

Platt, Harlan D. and Marjorie B. Platt. 2002. Predicting Corporate Financial Distress:Reflections on Choice-Based Sample Bias. Jurnals of Economics and Finance. 
Sigit. 2008. Akuntansi Keuangan Manufaktur. Edisi 1. Cetakan. Pertama. Yogyakarta : Graha Ilmu.

Sofyan Syafri Harahap. 2005. Teori Akuntansi Edisi Revisi. Jakarta: PT Raja Grafindo Persada.

Sofyan, Syafri Harahap. 2010. Analisis Kritis laporan Keuangan. Jakarta: PT. Raja Grafindo Persada.

Sugiyono. 2010. Metode Penelitian Bisnis. Bandung: Alfabeta

Sugiyono. 2012. Metode Penelitian Kuantitatif Kualitatif dan R\&D. Bandung: Alfabeta.

Sugiyono. 2014. Metode Penelitian Kuantitatif Kualitatif dan R\&D. Bandung: Alfabeta.

Syamsuddin. 2009. Manajemen Keuangan Perusahaan. Jakarta: PT. Raja Grafindo Persada.

Triwahyuningtias, Meilinda. 2012. Analisa Pengaruh Struktur Kepemilikan, Ukuran Dewan, Komisaris Independen, Likuiditas dan Leverage Terhadap Terjadinya Kondisi Financial Distress. Unpublished Thesis, Universitas Diponegoro. Semarang.

Wahyu, Widarjo dan Setiawan, Doddy. 2012. Pengaruh Rasio Keuangan Terhadap Kondisi Financial Distress Perusahaan Otomotif. Jurnal Bisnis dan Akuntansi. 11 (2): 107-119.

Wiagustini, Ni Luh Putu. 2010. Dasar-Dasar Manajemen Keuangan. Denpasar: Udayana University Press.

Widjaja, Amin Tunggal. 2010. Pokok-pokok Analisis Laporan Keuangan. Jakarta: Harvarindo. 